\title{
New Macrocyclic Diterpenoids from Jatropha multifida ${ }^{1)}$
}

\author{
Biswanath Das, ${ }^{*, a}$ Bommena RaviKanth,${ }^{a}$ Keetha LaXminarayana, ${ }^{a}$ Bethapudi RamaraO, ${ }^{a}$ and \\ Tuniki Venugopal RAJU ${ }^{b}$ \\ ${ }^{a}$ Organic Chemistry Division-I, Indian Institute of Chemical Technology; and ${ }^{b}$ NMR Division, Indian Institute of \\ Chemical Technology; Hyderabad-500 007, India. \\ Received November 25, 2008; accepted December 1, 2008; published online December 4, 2008
}

\begin{abstract}
Chemical investigation on the stems of Jatropha multifida resulted in the isolation of two new macrocyclic diterpenoids whose structures were established by extensive studies of their 1D and 2D-NMR spectra. The occurrence of ten other known compounds in this species is reported here for the first time.
\end{abstract}

Key words Jatropha multifida; Euphorbiaceae; stem; macrocyclic diterpenoid; structure elucidation

Jatropha multifida LinN (Euphorbiaceae), a shrub, is found in different parts of India. The plant is known to exhibit antibiotic activity. ${ }^{2)}$ Earlier examination of the latex of the plant afforded some cyclic peptides, phenolics and glucosides. ${ }^{3-5)}$ However, the investigation on other parts of the plant has not yet been reported.

In continuation of our work ${ }^{6-9)}$ on the constituents of Jatropha species we examined the stems of Jatropha multifida and isolated two new macrocyclic diterpenoids, $\mathbf{1}$ and $\mathbf{2}$ along with ten known compounds. Here, we describe the isolation of these constituents and structure elucidation of the unknown compounds.

Compound $\mathbf{1}$ was isolated as a semi solid. Its molecular formula was deduced to be $\mathrm{C}_{22} \mathrm{H}_{30} \mathrm{O}_{5}$ from its mass spectrum, elemental analysis and ${ }^{13} \mathrm{C}$-NMR spectrum. The IR spectrum of the compound indicated the presence of carbonyl group and unsaturation. The ${ }^{1} \mathrm{H}$ - and ${ }^{13} \mathrm{C}-\mathrm{NMR}$ spectral data of $\mathbf{1}$ (Table 1) clearly suggested that its structure is related to that of japodagrone $(3)^{10)}$ (a known constituent of Jatropha species) which has also presently been isolated from the investigated plant. All of the signals for the protons and carbons in the ${ }^{1} \mathrm{H}$ - and ${ }^{13} \mathrm{C}$-NMR spectra respectively, were assigned from 2D NMR $\left({ }^{1} \mathrm{H}-{ }^{1} \mathrm{H}\right.$ correlation spectroscopy (COSY), nuclear Overhauser effect spectroscopy (NOESY), heteronuclear single quantum coherence (HSQC) and heteronuclear multiple bonding connectivity (HMBC)) and dis-

Table 1. NMR Spectral Data of Compounds $\mathbf{1}$ and $\mathbf{2}^{a, b)}$

\begin{tabular}{|c|c|c|c|c|c|c|}
\hline \multirow{2}{*}{ Position } & \multicolumn{3}{|c|}{ Compound 1} & \multicolumn{3}{|c|}{ Compound $\mathbf{2}$} \\
\hline & ${ }^{1} \mathrm{H}-\mathrm{NMR}$ & $\begin{array}{l}\text { Multiplicity } \\
(J \text { in } \mathrm{Hz})\end{array}$ & ${ }^{13} \mathrm{C}-\mathrm{NMR}$ & ${ }^{1} \mathrm{H}-\mathrm{NMR}$ & $\begin{array}{l}\text { Multiplicity } \\
(J \text { in } \mathrm{Hz})\end{array}$ & ${ }^{13} \mathrm{C}-\mathrm{NMR}$ \\
\hline 1 & 7.30 & $\mathrm{~s}$ & 150.3 & 7.01 & $\mathrm{~s}$ & 153.3 \\
\hline 2 & - & - & 144.7 & - & - & 143.0 \\
\hline 3 & - & - & 195.2 & - & - & 208.2 \\
\hline 4 & - & - & 132.5 & 4.31 & $\mathrm{~d}$ & 50.4 \\
\hline 5 & 6.81 & $\mathrm{~s}$ & 139.7 & 5.02 & d & 114.7 \\
\hline 6 & - & - & 81.6 & - & - & 150.0 \\
\hline \multirow[t]{2}{*}{7} & (a) 1.89 & $\mathrm{~m}$ & 37.6 & (a) 1.93 & $\mathrm{~m}$ & 33.1 \\
\hline & (b) 1.86 & $\mathrm{~m}$ & 37.6 & (b) 1.91 & $\mathrm{~m}$ & 33.1 \\
\hline \multirow[t]{2}{*}{8} & (a) 1.82 & $\mathrm{~m}$ & 25.5 & (a) 1.88 & $\mathrm{~m}$ & 22.1 \\
\hline & (b) 1.65 & $\mathrm{~m}$ & & (b) 0.54 & $\mathrm{~m}$ & \\
\hline 9 & 3.73 & $\mathrm{t}(6.5)$ & 88.1 & 0.36 & $\mathrm{~m}$ & 26.8 \\
\hline 10 & - & - & 35.7 & - & - & 15.8 \\
\hline \multirow[t]{2}{*}{11} & (a) 1.30 & $\mathrm{~m}$ & 34.4 & 0.65 & $\mathrm{~m}$ & 19.1 \\
\hline & (b) 0.41 & $\mathrm{~m}$ & & & $\mathrm{~m}$ & \\
\hline \multirow[t]{2}{*}{12} & (a) 2.26 & $\mathrm{~m}$ & 30.9 & (a) 1.86 & $\mathrm{~m}$ & 27.8 \\
\hline & (b) 1.32 & $\mathrm{~m}$ & & (b) 1.76 & $\mathrm{~m}$ & \\
\hline 13 & 2.78 & $\mathrm{~m}$ & 43.5 & 3.61 & $\mathrm{~m}$ & 39.6 \\
\hline 14 & - & - & 204.6 & - & - & 213.1 \\
\hline 15 & - & - & 88.9 & - & - & 84.7 \\
\hline 16 & 1.93 & $\mathrm{~s}$ & 10.7 & 1.80 & $\mathrm{~s}$ & 10.2 \\
\hline 17 & 1.27 & $\mathrm{~s}$ & 24.0 & 1.82 & $\mathrm{~s}$ & 22.6 \\
\hline 18 & 0.91 & $\mathrm{~s}$ & 28.2 & 0.99 & $\mathrm{~s}$ & 28.7 \\
\hline 19 & 0.73 & $\mathrm{~s}$ & 23.4 & 0.78 & $\mathrm{~s}$ & 14.8 \\
\hline 20 & 0.97 & $\mathrm{~d}(7.0)$ & 20.6 & 1.22 & $\mathrm{~d}(7.0)$ & 15.9 \\
\hline$-\mathrm{OH}$ & - & - & - & 2.54 & brs & - \\
\hline$-\mathrm{OAc}$ & 2.09 & $\mathrm{~s}$ & $\begin{array}{r}169.3 \\
22.1\end{array}$ & - & - & - \\
\hline
\end{tabular}

a) The spectra were run in $\mathrm{CDCl}_{3}$ at $\left.500 \mathrm{MHz}\left({ }^{1} \mathrm{H}-\mathrm{NMR}\right), 100 \mathrm{MHz}\left({ }^{13} \mathrm{C}-\mathrm{NMR}\right) . \quad b\right)$ The signals were assigned with the help of $2 \mathrm{D}-\mathrm{NMR}\left({ }^{1} \mathrm{H}-{ }^{1} \mathrm{H} \mathrm{COSY}\right.$, $\mathrm{HMBC}$ and NOESY) and DEPT experiments. 
tortionless enhancement by polarization transfer (DEPT) experiments. These spectral data clearly revealed that the new compound $\mathbf{1}$ is the acetyl derivative of $\mathbf{3}$ which contains a hydroxyl group at $\mathrm{C}-15$. The acetoxy group in $\mathbf{1}$ was properly placed at $\mathrm{C}-15$ as in the ${ }^{13} \mathrm{C}$-NMR spectrum this carbon $(\delta$ 88.9) showed a downfield shift compared to the position of the corresponding carbon $(\delta 82.4)^{10)}$ of 3 . In the ${ }^{1} \mathrm{H}-\mathrm{NMR}$ spectrum $\mathrm{H}-1$ also showed a downfield shift ( $\delta 7.30$ in $\mathbf{1}$ while $\delta 6.80$ in 3$)^{10)}$ due to the deshielding effect of the -OAc group at C-15. Additionally, in the HMBC experiment (Fig. 1) C-15 showed correlations with H-5 $(\delta 6.81)$ and $\mathrm{H}-$ $13(\delta$ 2.78). The NOESY experiment suggested that both compounds $\mathbf{1}$ and $\mathbf{3}$ possess a similar relative stereochemistry. ${ }^{10)}$ The $-\mathrm{OAc}$ group at C-15 showed correlation with Me-20 (Fig. 1). The structure of $\mathbf{1}$ was thus clearly settled as 15 - $O$-acetyl japodagrone.

Compound 2 was obtained as a white solid. Its molecular formula was assigned as $\mathrm{C}_{20} \mathrm{H}_{28} \mathrm{O}_{3}$ from its mass spectrum, elemental analysis and ${ }^{13} \mathrm{C}$-NMR spectrum. The IR spectrum of the compound showed the presence of hydroxyl and carbonyl groups and unsaturation. The ${ }^{1} \mathrm{H}-\mathrm{NMR}$ spectral data (Table 1) revealed the presence of a cyclopropane moiety, two olefinic protons, a hydroxyl and five methyl groups. On the other hand, the ${ }^{13} \mathrm{C}-\mathrm{NMR}$ spectral data (Table 1) showed the presence of two tri-substituted double bonds, two carbonyl groups, five methyls, three methylenes, four methines and two quaternary carbons. A comparision of these ${ }^{1} \mathrm{H}$ - and ${ }^{13} \mathrm{C}-\mathrm{NMR}$ spectral data of 2 with those of the known constituents of Jatropha species suggested that the structure of the new compound is related to that of $(4 E)$-jatrogrossidentadione (4). ${ }^{11)}$ However, the double bond in the macrocyclic
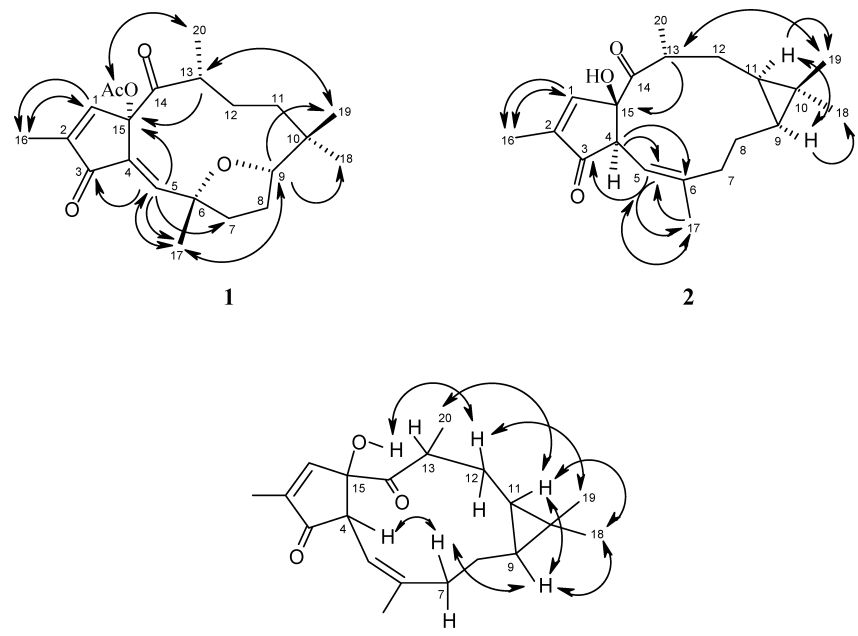

2a

Selected HMBC $(\bigodot)$ and NOESY correlations $(\bigodot)$

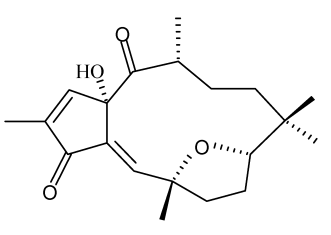

3

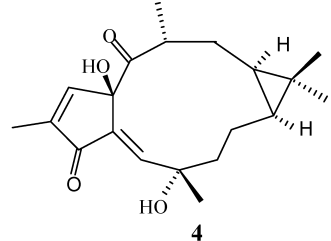

4
Fig. 1. Compounds Isolated from Jatropha multifida ring has been shifted to $\mathrm{C}-5, \mathrm{C}-6$ position in 2 . This was evident from the $2 \mathrm{D}-\mathrm{NMR}$ experiments. The ${ }^{1} \mathrm{H}-{ }^{1} \mathrm{H}$ COSY experiment showed that $\mathrm{H}-4(\delta 4.31)$ was correlated to $\mathrm{H}-5(\delta$ 5.02) while $\mathrm{HMBC}$ experiment demonstrated that $\mathrm{H}-4$ was related to $\mathrm{C}-1(\delta$ 153.3), C-6 $(\delta$ 150.0) and $\mathrm{C}-14(\delta$ 213.1), $\mathrm{H}-5$ to $\mathrm{C}-3(\delta$ 208.2), C-15 $(\delta$ 84.7) and C-17 $(\delta$ 22.6) and Me-17 $(\delta 1.82)$ to $\mathrm{C}-5(\delta 114.7)$ and $\mathrm{C}-7$ ( $\delta 33.1)$. The configuration of the double bond at C-5, C-6 was deduced to be (Z) from NOESY experiment which showed a clear correlation between $\mathrm{H}-5$ and Me-17. This experiment also indicated the similar stereochemistry of 2 at C-9, C-11 and C-13 as possessed by 4 . H-11 $(\delta 0.65)$ was found to correlate with $\mathrm{H}$ $9(\delta 0.36), \mathrm{Me}-18(\delta 0.99)$ and Me-20 ( $\delta$ 1.22) suggesting that these are all $\alpha$-oriented. H-9 showed correlation with one of the protons $(\delta 1.93)$ at $\mathrm{C}-7$ which again showed correlation with H-4. Similarly, Me-19 $(\delta$ 0.78) showed correlation with one of the protons $(\delta 1.76)$ at $\mathrm{C}-12$ which in turn showed correlation with the hydroxyl group $(\delta 2.54)$ at C-15. The NOESY results have also been shown in a conformational structure (2a) which has been established by following the X-ray crystallographic structure of a related molecule. ${ }^{12}$ $\mathrm{H}-4$ and $\mathrm{OH}-15$ was thus suggested to be $\alpha$ - and $\beta$-oriented respectively. Consequently the stereochemistry of the cyclopentenone ring junction with the macrocycle is derived to be trans. Thus the structure of the second new diterpenoid was deduced clearly as $\mathbf{2}$.

Along with new compounds 1 and 2 ten other constituents, tetradecyl- $(E)$-ferulate, ${ }^{13)}$ jatropholone-A, ${ }^{14)}$ jatropholone-B,${ }^{14)}$ jatrophenone, $\left.{ }^{6}\right)$ 4-butyl-2-chloro-5-formyl- $1 H$-imidazole, ${ }^{9)} 15$ epi-(4E)-jatrogrossidentadione, ${ }^{11)}$ (4E)-jatrogrossidentadione, ${ }^{11)}$ $3 \beta$-acetoxy-12-methoxy-13-methyl-podocarpa-8,11,13-trien7-one, ${ }^{8)} 3 \beta, 12$-dihydroxy-13-methyl-podocarpane-8,10,13triene $^{8)}$ and japodagrone ${ }^{10)}$ were also isolated. The structures of the known compounds were established by comparision of their physical and spectral properties with those reported in the literature. The occurrence of these known compounds in the investigated plant is reported here for the first time.

\section{Experimental}

General Melting points were measured in a Buchi-510 instrument and are uncorrected. The spectra were recorded with the following instruments; IR, Perkin Elmer RX1 FT-IR spectrophotometer; NMR, Varian Gemini $200 \mathrm{MHz}$, Brucker $300 \mathrm{MHz}$, Unity $400 \mathrm{MHz}$, Inova $500 \mathrm{MHz}$ and Avance $600 \mathrm{MHz}$; EI-MS: Micromass VG $7070 \mathrm{H}(70 \mathrm{eV})$, LSI-MS: Micromass Quattro LC, ESI-MS: LC-MSD-Trap-SL and HRMS: Applied Biosystems QSTAR XL instruments. The optical rotations were measured on a Jasco DIP-360 polarimeter, Column chromatography was performed over silica gel (BDH, 100-200 mesh) and TLC with silica gel $\mathrm{GF}_{254}$.

Plant Material The stems of Jatropha multifida were collected from the botanical garden, Osmania University campus, Hyderabad in June 2006. A voucher specimen (No. 56109) is preserved in IICT herberium.

Extraction and Isolation The shade dried plant material $(6 \mathrm{~kg})$ was powdered and extracted three times ( $72 \mathrm{~h}$ in each case) with $\mathrm{CHCl}_{3}-\mathrm{MeOH}$ $(1: 1,41)$ at room temperature. The total extract was concentrated to afford a thick brown mass $(120.4 \mathrm{~g})$. The residue $(120 \mathrm{~g})$ was subjected to column chromatography and the column was eluted with solvents of increasing polarity using hexane and EtOAc, separation of the components in the mixture being monitored by TLC.

The fractions eluted with hexane-EtOAc $(8: 2)$ contained a compound which was purified by rechromatography to yield tetradecyl- $(E)$-ferulate $(1.32 \mathrm{~g})$. From the fractions eluted with hexane-EtOAC $(7: 3)$ a mixture of three compounds were obtained and these were purified by rechromatography to afford jatropholone-A $(1.85 \mathrm{~g})$, jatropholone-B $(1.17 \mathrm{~g})$ and jatrophenone $(1.08 \mathrm{~g})$. The fractions eluted with hexane-EtOAc $(6: 4)$ were the mixture of three compounds, which on rechromatography furnished 4-butyl-2chloro-5-formyl- $1 \mathrm{H}$-imidazole $(180 \mathrm{mg}), 15$-epi-(4E)-jatrogrossidentadione 
$(152 \mathrm{mg})$ and $(4 E)$-jatrogrossidentadione $(82 \mathrm{mg})$. Purification of the fractions with hexane-EtOAC $(1: 1)$ yielded $3 \beta$-acetoxy-12-methoxy13-methyl-podacarpane-8,11,13-trien-7-one $(83 \mathrm{mg}), 3 \beta, 12$-dihydroxy-13methyl-podocarpane-8,10,13-triene $(51 \mathrm{mg})$ and japodagrone $(29 \mathrm{mg})$ while the purification of the fractions eluted with hexane-EtOAc $(4: 6)$ afforded compound $1(10 \mathrm{mg})$ and compound $2(4 \mathrm{mg})$.

Compound 1: Semi solid, $[\alpha]_{\mathrm{D}}^{25}-370.6\left(c=0.001, \mathrm{CHCl}_{3}\right)$; IR $(\mathrm{KBr})$ $v_{\max }: 1748,1712,1629,1460,1224 \mathrm{~cm}^{-1} ;{ }^{1} \mathrm{H}-$ and ${ }^{13} \mathrm{C}-\mathrm{NMR}$ : Table 1; ESIMS $m / z: 397[\mathrm{M}+\mathrm{Na}]^{+}$HR-MS $m / z: 397.1988$ (Calcd for $\mathrm{C}_{22} \mathrm{H}_{30} \mathrm{O}_{5} \mathrm{Na}: \mathrm{m} / \mathrm{z}$ 397.1990) (Found: $\mathrm{C}, 70.09 ; \mathrm{H}, 8.02 . \mathrm{C}_{22} \mathrm{H}_{30} \mathrm{O}_{5}$ required: $\mathrm{C}, 70.59 ; \mathrm{H}$, $8.02 \%)$

Compound 2: White solid, mp $143-145^{\circ} \mathrm{C},[\alpha]_{\mathrm{D}}^{25}+271.1 \quad(c=0.001$, $\mathrm{CHCl}_{3}$ ); IR (KBr) $v_{\max }: 3436,1722,1642,1461,1216 \mathrm{~cm}^{-1} ;{ }^{1} \mathrm{H}-$ and ${ }^{13} \mathrm{C}-$ NMR: Table 1; ESI-MS m/z: $317[\mathrm{M}+\mathrm{H}]^{+}$. HR-MS m/z: 339.1950 (Calcd for $\mathrm{C}_{20} \mathrm{H}_{28} \mathrm{O}_{3} \mathrm{Na}: \mathrm{m} / z$ 339.1936) (Found: $\mathrm{C}, 75.48 ; \mathrm{H}, 8.78 . \mathrm{C}_{20} \mathrm{H}_{28} \mathrm{O}_{3}$ required: $\mathrm{C}, 75.95 ; \mathrm{H}, 8.86 \%$ ).

Acknowledgements The authors thank CSIR and UGC, New Delhi for financial assistance.

\section{References and Notes}

1) Part 69 in the series "Studies on Phytochemicals."

2) Aiyelaagbe O. O., Fitoterpia, 72, 544-546 (2001).

3) Kosasi S., Van der Sluis W. G., Boelens, R., Hart L. A., Labadie R. P.,
FEBS Lett., 256, 91—96 (1989).

4) Kosasi S., Van der Sluis W. G., Labadie R. P., Phytochemistry, 28, 2439-2441 (1989).

5) Van den Berg A. J. J., Horsten S. F. A. J., Van Den Bosch J. J. K., Kroes, B. H., Labadie R. P., Phytochemistry, 40, 597-598 (1995).

6) Ravindranath N., Venkataiah B., Ramesh C., Jayaprakash P., Das B., Chem. Pharm. Bull., 51, 870-871 (2003).

7) Ravindranath N., Reddy M. R., Mahender G., Ramu R., Ravikumar K., Das B., Phytochemistry, 65, 2387-2390 (2004).

8) Ravindranath N., Reddy M. R., Ramesh C., Ramu R., Prabhakar A., Jagadeesh B., Das B., Chem. Pharm. Bull., 52, 608-611 (2004).

9) Das B., Reddy M. R., Kishore N. R. K. H., Murthy U. S. N., Indian J. Chem., 44B, 1119-1120 (2005).

10) Aiyelaagbe O. O., Adesogan K., Ekundayo O., Gloer J. B., Phytochemistry, 68, 2420-2425 (2007).

11) Schmeda-Hirschmann G., Tsichritzis F., Jakupovic J., Phytochemistry, 31, 1731-1735 (1992).

12) Brum R. L., Cavalheiro A. J., Monache F. D., Vencato I., J. Braz. Chem. Soc., 12, 259-262 (2001).

13) Kavitha J., Rajashekar D., Subbaraju G. V., J. Asian Nat. Prod. Res., 2, 51-54 (1999).

14) Purushothaman K. K., Chandrasekharan S., Cameron A. F., Connolly J. D., Labbe C., Maltz A., Rycroft D. S., Tetrahedron Lett., 20, 979980 (1979). 